\title{
The subjective familiarity of English homophones
}

\author{
ROGER J. KREUZ \\ Princeton University, Princeton, New Jersey
}

\begin{abstract}
College students rated 828 homophonic words (words with the same pronunciation but different spellings) in terms of subjective familiarity. High interrater reliability was obtained, and the ratings correlated well with other published familiarity measures $(r=.85)$. The familiarity ratings also correlated highly with log transforms of Kucera and Francis's (1967) printed frequency measures $(r=.75)$. However, many words of equal log frequency varied widely in rated familiarity, and vice versa. To determine which of these two factors was the better predictor of verbal performance, we orthogonally varied the two in a lexical decision task and found that, for words of moderate frequency, rated familiarity was by far the better predictor. We conclude that even though printed frequency and rated familiarity generally covary, printed frequency is a less reliable index of the underlying psychological construct, word familiarity.
\end{abstract}

Many researchers have tried to explain wordrecognition effects by placing heavy emphasis on the role of word frequency (e.g., Forster \& Bednall, 1976; Morton, 1969; Oldfield \& Wingfield, 1965; Pierce, 1963). Despite the theoretical and experimental importance of this factor, few researchers have explicitly described what they mean when they refer to the frequency of a word. Most psychologists who work in this area have simply relied on one of the several indexes that have been compiled to measure how frequently a word appears in printed English.

Although printed frequency is one measure of how familiar a word is to people, it may not be the best measure for use in psychological research. The Teacher's Word Book of 30,000 Words (Thorndike \& Lorge, 1944) has been used extensively by those interested in manipulating word frequency, even though several researchers have pointed out its defects. For example, Roberts (1965) expressed concerns about the sources upon which the Thorndike-Lorge count was based, and Rosenzweig and McNeil (1962) cited errors in the reporting of frequency information. Other investigators have echoed these complaints and have highlighted other problems as well (Gernsbacher, 1984; Howes, 1954; Shapiro \& Gordon, 1971).

The frequency counts based on the Brown Corpus (Francis \& Kučera, 1982; Kučera \& Francis, 1967) avoid most of these problems, but others remain. Carroll (1967) pointed out that the Brown Corpus is, after all, only a

This research was supported by NSF Grant BNS 82-06461 to Princeton University, Sam Glucksberg, principal investigator. I would like to thank Sam Glucksberg for his help in designing the experiments and John $\mathrm{H}$. Fleming for his assistance with the statistical analyses. Catherine Hanson, William Hirst, and William Prinzmetal provided insightful critiques of earlier drafts of the manuscript; the comments of Morton Gernsbacher, Roberta Ann Goodman, and an anonymous reviewer were also helpful. Correspondence concerning this article should be addressed to Roger J. Kreuz, Department of Psychology, Green Hall, Princeton University, Princeton, NJ 08544. sample of the language and therefore is subject to sampling error. Gernsbacher (1983) demonstrated that lowfrequency words vary a great deal in terms of subjective familiarity and that many inconsistencies in the wordrecognition literature can be attributed to this confound (Gernsbacher, 1984). When familiarity ratings are substituted for printed frequency ratings, these inconsistencies are resolved.

Two recent studies provide further evidence that subjective familiarity is a better predictor of word-recognition latencies than are printed frequency counts. Both Gordon (1985) and Nusbaum, Pisoni, and Davis (1984), utilizing different procedures, found that familiarity ratings accounted for more of the variance in reaction times than did the Kučera and Francis (1967) count. Unfortunately, their familiarity ratings are not widely available, and researchers who wish to control for subjective familiarity must first collect their own ratings or consult the rather limited corpora that are available (e.g., Toglia \& Battig, 1978).

Of course, some types of words are utilized more frequently than others in psychological experiments, because they possess unique properties. Familiarity ratings for these words would be a valuable addition to the norms that are currently available. One such group of words is the homophones of English. Homophones have been used to explore phenomena as diverse as surface dyslexia (Temple, 1984), conduction aphasia (Friedrich, Glenn, \& Marin, 1984), evoked potential topography (Brown, Lehmann, \& Marsh, 1980), long-term memory (Nelson \& Rothbart, 1972), short-term memory (Kintsch \& Buschke, 1969), and phrase evaluation (Baron, 1973; Doctor \& Coltheart, 1980). Perhaps most importantly, homophones have been used to shed light upon lexical access and phonological recoding (Coltheart, Davelaar, Jonasson, \& Besner, 1977; Davelaar, Coltheart, Besner, \& Jonasson, 1978; Rubenstein, Lewis, \& Rubenstein, 1971; Winshel \& Glucksberg, 1985). 
Despite the widespread use of homophones in cognitive psychology and cognitive neuroscience, no one has collected familiarity ratings for these words. In fact, no satisfactory compilation of the words themselves can be found in the psychological literature. Only two small sets of homophones have been published previously. One collection, by G. G. Galbraith and Taschman (1969), lists several association and latency measures for 88 homophone pairs. The other compilation, by Olson and Kausler (1971), contains a list of 139 homophone pairs, together with ratings of "orthographic distinctiveness." (Because of duplications, these two sources provide only 163 homophone pairs.) Homophone collections also appear outside the psychological literature (Ellyson, 1977; Espy, 1972; Kilpatrick, 1985; Whitford, 1966).

The available homophone lists, however, have serious drawbacks for use in empirical research. All of these collections are incomplete, and many of them use idiosyncratic criteria to determine which words are homophones. Most importantly, they lack any index of frequency, although the G. G. Galbraith and Taschman (1969) collection does provide Thorndike and Lorge (1944) frequencies. The lack of a satisfactory collection of homophones is particularly surprising, given the plethora of corpora for other "exceptional" words (see Bradshaw, 1984, for a review). This paper addresses this need by providing a comprehensive and standardized listing of homophones, including their frequency in the Brown Corpus (Kučera \& Francis, 1967), a measure of their subjective familiarity, and an explication of the relative predictive power of frequency versus familiarity in an experimental context.

\section{THE HOMOPHONES OF ENGLISH}

Because there seems to be some confusion in the literature regarding the use of the terms homonym, homograph, and homophone, a few words of clarification may be useful. Homophones are two or more words that are pronounced alike, but are different in derivation, meaning, or spelling (e.g., bear and bare). A homograph refers to two or more words that are spelled alike, but are different in derivation, meaning, or pronunciation (e.g., the noun and verb senses of the word bear). The term homonym can be used to refer to homophones, to homographs, or to two or more words spelled and pronounced alike, but different in meaning. In the psychological literature, homographs and homonyms (in two of its senses) are more commonly referred to as polysemous, or lexically ambiguous, words.

The homophones listed in Appendix A have been culled from the various homophone corpora cited above. However, many of the words appearing in these sources are not true homophones. In order to achieve some measure of consistency, the following criteria were employed to compile the list presented here:

(1) Pronunciation: Only words that have exactly the same pronunciation, according to Webster's New Collegiate Dictionary (1977), are included. For cases in which several acceptable pronunciations are possible, words that share at least one possible pronunciation are included. Because of this fairly liberal pronunciation criterion, not all of the words listed here are homophonic in all the dialects of American English. For example, the triplet "Mary, marry, merry" is homophonic for most Midwest speakers but not for most Northeast speakers.

(2) Stress: Words that differ by stress are not included (e.g., incite, insight).

(3) Variants: Words that are spelling variants of one another (e.g., ax, axe) are not included. Most of these words simply reflect spelling differences between British and American English and are not true homophones.

(4) Currency: If a word is defined as "chiefly British," "chiefly Scottish," or "archaic" in all senses in Webster's New Collegiate Dictionary (1977), it is not included here.

(5) Scope: Except for certain proper nouns, we have included only words appearing in Webster's New Collegiate Dictionary (1977).

(6) Frequency: All the words appearing in Appendix A also appear in Kučera and Francis (1967); that is, they all occur at least once in the million-word sample that makes up the Brown Corpus. Although this constraint eliminates many words that meet the other criteria, we did this to avoid cluttering the list with too many rare and unfamiliar words. ${ }^{1}$

Within the constraints of these criteria, the corpus contains almost all of the homophones in the sources cited above and therefore includes the vast majority of true English homophones.

Words that are marked with an asterisk in Appendix A are not only homophones, but are also heteronyms; that is, they possess "multiple phonemic representations" (Martin, Jones, Nelson, \& Nelson, 1981, p. 299). An example is the word read, which can be pronounced to rhyme with "deed" or with "head." In this case, both pronounciations of the heteronym are homophonic (i.e., with "reed" and with "red"). These words are marked because measures of their printed frequency are artificially inflated; both senses of the word are being counted together. In addition, these words also raise problems for estimations of subjective familiarity, because it is not clear which sense of the word is being rated. (This point will be clarified in the description of Experiment 1.) Such words are therefore multiply ambiguous, and their use as stimulus materials in psychological experiments should be avoided.

Once a suitable set of homophonic words had been collected, the next step was to obtain subjective familiarity ratings for each entry in the homophone corpus. Experiment 1 describes how the ratings were generated.

\section{EXPERIMENT 1}

\section{Method}

Subjects. Sixty undergraduate students at Princeton University served as paid volunteers; all were native English speakers. 
Materials. Homophones that met all the criteria described above constituted the experimental materials. A total of 828 homophonic words were selected (see Appendix A). In addition, 15 nonhomophonic words were used as control items. These control words were selected at random from the 1-, 10-, and 100-per-million sections of Kučra and Francis (1967); 5 from each section were used. These words are listed in Appendix B.

Procedure. Because of the large number of words to be rated, each subject was asked to rate only a quarter of the total. The list of homophones was randomized, and four separate lists of words were created. The lists were constrained such that no subject rated both members of a homophone pair. For example, if the word waste appeared in List 1, the word waist was put into one of the other three lists. The 209 homophones (and 15 control words) in each list were printed on the left-hand side of the questionnaire pages, with 14 words appearing on each page. ${ }^{2}$ To the right of each word was an unnumbered, 7-point Likert format scale with endpoints labeled "very uncommon" and "very common." The midpoint of the scale was labeled "neither uncommon nor common." The questionnaire booklets consisted of a page of instructions and 16 pages of words to be rated. To avoid any confound of ordering effects, the page order was counterbalanced in the booklets.

The subjects read the following instructions:

On the following pages you will find a list of words. Some of these words will be words that you know, and use very often. That is, they are VERY COMMON words. Others will be words that you might have never seen before, and surely do not use very often. Thus, they are VERY UNCOMMON words. Of course, there will also be words that fall between these two extremes. What we want you to do is read through the list, and for each word, mark how COMMON or UNCOMMON you believe each one to be.

You will have a 7-point scale on which to record your responses. To mark your rating, simply check the space that you think best applies for each word. When you are rating these words, try to use the full range of the scale. If you occasionally feel unsure, just make your best judgment. Don't leave any items unmarked. Keep in mind that this is not a test of your knowledge of words; we are simply interested in your intuitions.

Before you begin to make your ratings, it would be a good idea to briefly read through the first twenty or so words on the list, so you will have a general feel for the overall make-up of the list. If you have any questions, ask the experimenter before you begin. Thank you for your participation. ${ }^{3}$

\section{Results and Discussion}

Each homophone was rated by 15 subjects. (Eight of the homophones were rated by 30 subjects, and are so marked in Appendix A; see Footnote 2.) The control words were judged by all 60 subjects. For each word, a mean rating and standard deviation were computed. These results can be found in Appendices A and B under the columns labeled "Familiarity." The variability in ratings for each word was generally low; the mean standard deviation for all words was 1.20. Most of the words of higher variability were proper nouns.

The interrater reliability of the subjects who rated the same lists of words was uniformly high, exceeding .98 for each of the four lists. The 15 nonhomophonic controls used on all four lists made it possible to calculate the interrater reliability across all subjects for all lists. This value was also high, exceeding .88 .
In conducting this experiment, we were concerned about whether the subjects were aware that almost all the words they were rating were homophonic. It is possible that such an awareness could have affected the ratings of the subjects. As a check on this possibility, the subjects were debriefed individually. They were asked if they had noticed anything "strange or unusual" about the list of words they had been asked to rate. Only 3 or 4 of the 60 subjects expressed any recognition of the fact that they had encountered homophones, and these subjects did not think that this awareness affected their responses in any way. ${ }^{4}$

\section{WHAT DOES FAMILIARITY MEASURE?}

The subjects were able to make reliable judgments of familiarity in Experiment 1; however, it remains to be seen whether the intuitions of our subjects agree with those of a different population. Toglia and Battig (1978) published ratings on seven different dimensions, including familiarity, for over 2,800 words. In addition, they described the concept of familiarity to their subjects in a way similar to the instructions in the present study. Although they employed a 7-point rating scale, as in the present study, they included nonwords in their stimulus materials. Consequently, their subjects may have used the low end of the scale differently from the way our subjects did. Despite this putative source of variation, the correlation between the two familiarity measures for the 422 words that appear in both the present study and the Toglia and Battig corpus is quite high $(r=.85, p<.01)$.

Subjective familiarity should not, however, be confused with measures of word frequency. The correlation between our subjective familiarity measures and the Brown Corpus printed frequency ratings for all 843 words was quite small $(r=.17, p<.01)$. When subjective familiarity and printed frequency are plotted against each other, the distribution exhibits a pronounced negative acceleration: Most of the words are clustered at the low end of the frequency scale, and a few very high-frequency words (e.g., the, in) appear at the top of the familiarity scale. Therefore, following Carroll (1971) and Shapiro (1969), we attempted to fit the data to a linear model by performing a logarithmic transformation on the printed frequency variable. When this was done, the correlation of log frequency and familiarity was much higher $(r=.75$, $p<.01$; see Figure 1), but there are numerous words that are not predicted well by a linear model. Indeed, we found, as had Gernsbacher (1984) and Gordon (1985), that the relationship between familiarity and printed frequency was weakest at the low end of the function.

Why should subjective familiarity and printed frequency differ from one another? One factor seems to be the concreteness of words. R. B. Galbraith and Underwood (1973) showed that, when printed frequency is held constant, subjects rate abstract words as having higher sub- 


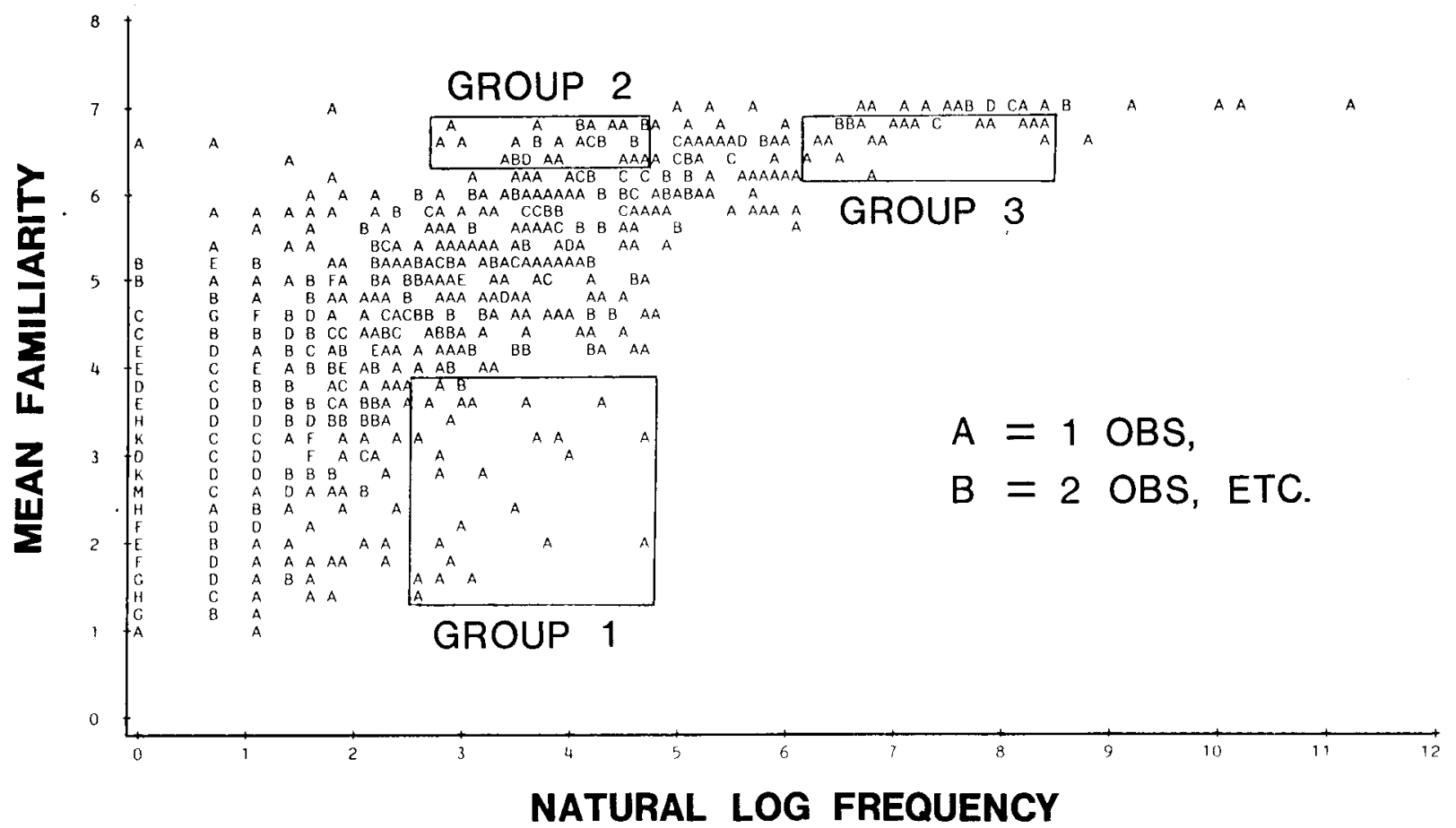

Figure 1. Scatterplot of mean subjective familiarity and printed log frequency from Experiment 1 and word group regions from Experiment 2.

jective familiarity than concrete words. A more important factor may be the difference between spoken and written language. Our subjects judged contractions and certain colloquial words (e.g., guys) as having high familiarity, even though these words possess only a moderate printed frequency. Thus, familiarity judgments may reflect spoken, not written, language use.

There are, however, a couple of potential problems in interpreting Experiment 1 . Since the subjects were unaware that they were rating homophones, they may have confused the meanings of visually similar words (e.g., thinking of to change when rating altar). We checked this by separately analyzing 25 homophone pairs that have high orthographic distinctiveness (Olson \& Kausler, 1971) and 25 pairs with low distinctiveness. For the 25 visually similar pairs, the log frequency/familiarity correlation was .829 ; for the 25 dissimilar pairs, it was .825 (both $p s<.01)$. Not surprisingly, this difference was not significant by Fisher's $z$ test $(z=.06$, n.s. $)$. It therefore is unlikely that visually similar words were a source of confusion.

Other potential confounds in the study concern the presence of polymorphemic words and proper nouns. We based our frequency counts from Kučera and Francis (1967) on "surface" frequency, which can differ greatly from root frequency. For example, our subjects may have based their evaluation of the polymorphemic word guessed on its root monomorphemic form guess, which has a much higher frequency. This factor has been shown to affect lexical access (Taft, 1979).
To explore this possibility, we divided the 843 rated words into separate groups and found 48 proper nouns, 636 monomorphs, and 159 polymorphs. The correlation of $\log$ frequency and familiarity for proper nouns was .54 $(p<.01)$, lower than the overall correlation of .75. This is not surprising, given the higher variability in the responses for these words. For the polymorphs, the correlation between $\log$ root frequency and familiarity was .57 $(p<.01)$. The log surface frequency/familiarity correlation, however, was much higher $(r=.74, p<.01)$, and the two correlations differed significantly $(z=2.67$, $p<.01)$. It is likely, therefore, that the subjects were indeed evaluating the words themselves, and not some underlying root form.

\section{EXPERIMENT 2}

For homophonic words, is subjective familiarity a better predictor of verbal behavior (e.g., of word recognition latency and threshold detection) than is printed frequency? Although Gernsbacher (1984) answered affirmatively for words of low frequency, these are the words most affected by sampling error in the Brown Corpus. However, both Gordon (1985) and Nusbaum et al. (1984), using a broader range of words, found similar results. We therefore predicted that recognition latencies to homophones would be better accounted for by subjective familiarity than by printed frequency.

In order to test our measure of familiarity against frequency, we selected words of moderate and high fre- 
quency from those rated in Experiment 1 . Such words should not be affected by the confound of sampling error. In order to obtain word-recognition latencies for these words, we utilized a lexical decision task, described below.

\section{Method}

Subjects. Ten Princeton University undergraduates served as paid volunteers. None had participated in Experiment 1, and all were native English speakers.

Materials. Three different groups of 15 words each were employed; they were selected from the three regions that are indicated in Figure 1. In choosing words from these regions, we decided against utilizing proper nouns and contractions, but otherwise employed no explicit criteria. The three word groups had the following characteristics: Group 1-low-familiarity/moderate-frequency words (with a mean familiarity of 2.81 and a mean log frequency of 3.48) ${ }^{\text {; }}$; Group 2-high-familiarity/moderate-frequency words (with a mean familiarity of 6.52 and a mean log frequency of 3.64 ); Group 3-high-familiarity/high-frequency words (with a mean familiarity of 6.64 and a mean $\log$ frequency of 6.99 ).

The words in Groups 1 and 2 do not differ in terms of $\log$ frequency $(t=-.84$, n.s.), but they do differ in terms of familiarity $(t=-17.38, p<.01)$. In contrast, the words in Groups 2 and 3 differ in $\log$ frequency $(t=-17.09, p<.01)$ but not in familiarity $(t=-1.85$, n.s.). In addition, these three groups were equated in terms of number of letters. An analysis of variance (ANOVA) showed no difference among the three groups in terms of word length $[F(2,42)<1]$. The individual words, along with their statistics, appear in Appendix A.

In addition, 15 nonhomophonic filler words were used. These words were also used as fillers in Experiment 1 (see Appendix B). Finally, the subjects also were shown 60 pronounceable nonwords (e.g., HAWP, FELOB).

If subjective familiarity is a better predictor of word recognition latency than is printed frequency, then the reaction times (RTs) for words in Group 2 should be significantly faster than those for the words in Group 1. There should be no significant difference between the RTs for words in Groups 2 and 3. Conversely, if frequency is the better predictor, then a very different set of results should emerge. The RTs for Groups 1 and 2 should not differ significantly, and there should be a significant difference between Groups 2 and 3.

Procedure. A lexical decision task was employed. Each subject was tested individually in a sound-attenuating booth containing a cathode-ray tube (CRT) display and response keys. One response key, operated with the left index finger, simultaneously initiated a trial and started a software timer accurate to within $1 \mathrm{msec}$. Two right-hand keys, designated "yes" and "no," were used by the subject to respond. At the beginning of each trial, the subject viewed a fixation pattern in the center of the display. When the "ready" key was pressed, the pattern was replaced by a letter string in the center of the field, and the timer was started. Pressing either response key removed the letter display and stopped the timer. The experiment was controlled by a Commodore Model 2001 PET computer.

The subjects were told that strings of letters would appear on the display and that their task was to docide, as quickly and as accurately as possible, whether the letter strings were words. If a string was a word, the correct response was "yes"; if it was not a word, the correct response was "no." The subjects were then given 20 practice trials, during which they were to respond "yes" and "no" to the words YES and NO, respectively, as they appeared, one at a time, on the CRT display. At the beginning of the experimental block, the subjects saw 10 filler words and nonwords and then the 60 words and 60 nonwords described above. Two different random presentation orders were used to mitigate ordering effects.

\section{Results and Discussion}

For each word type, a mean RT was calculated from correct responses only. Only 1 response (of 1,190 ) exceeded 4,000 msec; this RT was counted as an error and was not included in the analyses. An ANOVA applied to these data showed that there was a significant main effect of word type (Group 1, 2, or 3) $[F(2,16)=73.18$, $p<.01]$. The effect of presentation order was not significant $[F(1,8)<1]$, and order did not interact with word type $[F(2,16)<1]$.

The RT means for each of the three word types are presented in Table 1. As can be seen, there was a 189msec difference between the two groups that had the same $\log$ frequency but different familiarity ratings. A Newman-Keuls test indicated that this difference was significant at the .01 level. Moreover, the two groups that were matched in terms of familiarity but not in log frequency differed by only $5 \mathrm{msec}$.

In order to examine the familiarity/frequency relationship in another way, the mean RTs for individual words were correlated against the measures of frequency and familiarity. The correlation between the RTs for the words in Groups 1 to 3 and $\log$ frequency was a negative one $(r=-.38, p<.05)$. The correlation between RTs and subjective familiarity ratings, however, was much higher $(r=-.82, p<.01)$. The difference between the correlations is significant by Fisher's $z$ test $(z=3.70$, $p<.01)$. Familiarity, therefore, seems to be a better predictor of word-recognition latencies than is printed frequency, at least for words of moderate frequency.

In a lexical decision task, a subject can make an incorrect response to a word for one of two reasons. It may

Table 1

Mean Reaction Time (RT; in Milliseconds) as a Function of Word Type

\begin{tabular}{lccc}
\hline & & Word Type & \\
\cline { 2 - 4 } & $\begin{array}{c}\text { Low Familiarity/ } \\
\text { Moderate Frequency } \\
\text { (Group 1) }\end{array}$ & $\begin{array}{c}\text { High Familiarity/ } \\
\text { Moderate Frequency } \\
\text { (Group 2) }\end{array}$ & $\begin{array}{c}\text { High Familiarity/ } \\
\text { High Frequency } \\
\text { (Group 3) }\end{array}$ \\
\hline RT* $^{*}$ & $746^{\mathrm{a}}$ & $557^{\mathrm{b}}$ & $562^{\mathrm{b}}$ \\
SD & 103 & 87 & 68 \\
Error Rate & $21 \%$ & $2 \%$ & $0.7 \%$ \\
\hline *Means not sharing a superscript differ by Newman-Keuls test $(p<.01)$.
\end{tabular}


be that the subject pressed the wrong key while attempting to respond as quickly as possible. This would be an example of a speed-accuracy trade-off (see Fitts, 1966; Pachella, 1974). It is also possible that the subject actually meant to press the "no" key and did so because the word was not a familiar one. This latter possibility would predict that subjects should have a higher error rate for the words in the low-familiarity condition.

Analysis of the error data supports this latter hypothesis. The error rates for the three conditions were not homogeneous. For Group 1, the overall error rate was $21 \%$. For Groups 2 and 3, the error rates were $2 \%$ and $.7 \%$, respectively. An ANOVA of the error rates showed that this factor was significant $[F(2,16)=20.51$, $p<.01]$. Once again, there was no main effect or interaction of presentation order (both $F \mathrm{~s}<1$ ). According to a Newman-Keuls test, the error rate for words in the lowfamiliarity condition (Group 1) differed at the .01 level from the error rates in the two high-familiarity conditions (Groups 2 and 3). As Table 1 indicates, the pattern of errors parallels the RT data.

Information obtained from the subjects during debriefing also supports this explanation of the error rate differences. Several subjects admitted they were not familiar with all the words they had seen. For example, the words effluent and wright were often missed, and many subjects professed an ignorance of their existence. It seems clear, then, that the error rate difference was not the result of subjects' sacrificing accuracy for speed.

\section{GENERAL DISCUSSION}

Our goal has been to provide subjective familiarity ratings for a large number of English homophones, words that are frequently utilized in psychological research. We documented that many of these words vary widely in terms of printed frequency measures and subjective familiarity ratings. Finally, we demonstrated that subjective familiarity ratings provide a better account of recognition latencies than do counts based on printed word frequency.

As noted above, Gernsbacher (1983) called attention to this problem in connection with low-frequency words (i.e., words occurring only once in the Thorndike-Lorge count). Because of the possible confound of sampling error in Thorndike-Lorge's and other corpora, it was not possible to extend her findings to more common words. However, the present study utilized words of higher printed frequency. The stimulus words in Groups 1 and 2 of Experiment 2 have printed frequencies ranging from 16 to 109 per million; they are not low-frequency words and should be much less affected by sampling error. In addition, recent work by Gordon (1985) and Nusbaum et al. (1984) also demonstrated the superiority of familiarity measures over a wide range of word frequency.

The only conclusion that seems to account for these results is that subjective familiarity is more sensitive than printed frequency in measuring the underlying psychological construct of word familiarity. The two measures are highly correlated (as we have shown) but differ significantly for a substantial number of words. Furthermore, there is no way to predict a priori which words will differ on these dimensions.

Our conclusions have implications for research involving linguistic materials. Word-frequency effects are commonly controlled for in a wide variety of experimental paradigms (e.g., semantic and lexical decision tasks; see Shoben, 1982), and the Kučera and Francis (1967) norms are widely used for this purpose. Although concerns about stimulus familiarity have been raised previously (e.g., McCloskey, 1980), this issue has not generated as much attention as it may deserve. However, a growing body of evidence, including the present study, suggests that this issue is an important one.

At any rate, the frequency/familiarity confound can be controlled for fairly easily, simply by utilizing familiarity measures instead of frequency counts. The norms published by Toglia and Battig (1978) and those presented here provide familiarity ratings for over 3,000 words. In addition, it is a simple matter to collect such ratings for words that do not appear in these corpora. An awareness of potential frequency/familiarity confounds should be kept in mind when conducting research with linguistic materials.

\section{REFERENCES}

Baron, J. (1973). Phonemic stage not necessary for reading. Quarterly Journal of Experimental Psychology, 25, 241-246.

Bradshaw, J. L. (1984). A guide to norms, ratings, and lists. Memory \& Cognition, 12, 202-206.

Brown, W. S., LehmanN, D., \& MarSh, J. T. (1980). Linguistic meaning related differences in evoked potential topography: English, SwissGerman, and imagined. Brain \& Language, 11, 340-353.

CARRoLL, J. B. (1967). On sampling from a lognormal model of wordfrequency distribution. In H. Kuxera \& W. N. Francis, Computational analysis of present-day American English (pp. 406-424). Providence, RI: Brown University Press.

CARRoll, J. B. (1971). Measurement properties of subjective magniude estimates of word frequency. Journal of Verbal Leaming \& Verbal Behavior, 10, 722-729.

Coltheart, M., Davelaar, E., Jonasson, J. T., \& Besner, D. (1977). Access to the internal lexicon. In S. Dornic (Ed.), Attention and performance VI. Hillsdale, NJ: Erlbaum.

Davelaar, E., Coltheart, M., Besner, D., Jonasson, J. T (1978). Phonological recoding and lexical access. Memory \& Cogni tion, 6, 39l-402.

Doctor, E. A., \& Coltheart, M. (1980). Children's use of phonological encoding when reading for meaning. Memory \& Cognition, 8, 195-209.

ELLYSON, L. W. (1977). A dictionary of homonyms. Mattituck, NY: Amereon House.

EspY, W. R. (1972). The game of words. New York: Bramhall House. FirTs, P. M. (1966). Cognitive aspects of information processing: III. Set for speed versus accuracy. Journal of Experimental Psychology, 71, 849-857.

Forster, K. I., Bednall, E. S. (1976). Terminating and exhaustive search in lexical access. Memory \& Cognition, 4, 53-61.

Francis, W. N., \& Kučera, H. (1982). Frequency analysis of English usage: Lexicon and grammar. Boston: Houghton Mifflin.

Friedrich, F. J., GlenN, C. G., \& Marin, O. S. (1984). Interruption of phonological coding in conduction aphasia. Brain \& Language, 22, 266-291 
Galbraith, G. G., \& Taschman, C. S. (1969). Homophone units: A normative and methodological investigation of the strength of component elements. Journal of Verbal Learning \& Verbal Behavior, 8 , 737-744.

Galbraith, R. B., \& Underwood, B. J. (1973). Perceived frequency of concrete and abstract words. Memory \& Cognition, 1, 56-60.

GerNSBACHER, M. A. (1982). The experiential familiarity of low frequency words. Unpublished manuscript, University of Texas at Austin, Austin, TX.

Gernsbacher, M. A. (1983, April). The experiential familiarity norms and their psychological reality. Paper presented at the meeting of the Southwestern Psychological Association, San Antonio, TX.

Gernsbacher, M. A. (1984). Resolving 20 years of inconsistent interactions between lexical familiarity and orthography, concreteness, and polysemy. Journal of Experimental Psychology: General, 113, 256-281.

GoRDON, B. (1985). Subjective frequency and the lexical decision latency function: Implications for mechanisms of lexical access. Journal of Memory \& Language, 24, 631-645.

Henderson, L. (1982). Orthography and word recognition in reading. New York: Academic Press.

HowEs, D. (1954). On the interpretation of word frequency as a variable affecting speed of recognition. Joumal of Experimental Psychology, 48, 106-112.

KILPATRICK, J. J. (1985). The ear is human: A handbook of homophones and other confusions. New York: Andrews, McMeel \& Parker.

KINTSCH, W., \& BusChKE, H. (1969). Homophones and synonyms in short-term memory. Journal of Experimental Psychology, 80, 403-407.

KuČERA, H., \& FranCIs, W. N. (1967). Computational analysis of present-day American English. Providence, RI: Brown University Press.

Martin, M., Jones, G. V., Nelson, D. L., Nelson, L. (1981). Heteronyms and polyphones: Categories of words with multiple phonemic representations. Behavior Research Methods \& Instrumentation, 13, 299-307.

MCCLOsKey, M. (1980). The stimulus familiarity problem in semantic memory research. Journal of Verbal Learning \& Verbal Behavior, 19, 485-502.

MorTon, J. (1969). Interaction of information in word recognition. Psychological Review, 76, 165-178.

Nelson, T. O., \& Rothbart, R. (1972). Acoustic savings for items in long-term memory. Journal of Experimental Psychology, 93, 357-360.

Nusbaum, H. C., Pisoni, D. B., \& Davis, C. K. (1984). Sizing up the Hoosier mental lexicon: Measuring the familiarity of 20,000 words (Research on Speech Perception Progress Report No. 10). Blooming ton: University of Indiana, Speech Research Laboratory.

OLDFTELD, R. C., \& WINGFIELD, A. (1965). Response latencies in naming objects. Quarterly Journal of Experimental Psychology, 17, 273-281

Olson, G. A., KaUsLer, D. H. (1971). Orthographic distinctiveness of homonyms. Behavior Research Methods \& Instrumentation, 3, 298-299.

Pachella, R. G. (1974). The interpretation of reaction time in information processing research. In B. Kantowitz (Ed.), Human information processing: Tutorials in performance and cognition. Hillsdale, NJ: Erlbaum

PIERCE, J. (1963). Some sources of artifact in studies of the tachistoscopic perception of words. Joumal of Experimental Psychology, 66, 363-370.

RoBerTs, A. H. (1965). A statistical linguistic analysis of American English. The Hague: Mouton.

RosenZWEIG, M. R., \& MCNEIL, D. (1962). Inaccuracies in the semantic count of Lorge and Thorndike. American Journal of Psychology, 75, 316-319.

Rubenstein, H., Lews, S. S., \& Rubenstein, M. A. (1971). Evidence for phonemic recoding in visual word recognition. Journal of Verbal Learning \& Verbal Behavior, 10, 645-657.

SHAPIRo, B. J. (1969). The subjective estimation of relative word frequency. Journal of Verbal Learning \& Verbal Behavior, 8, 248-251.

ShAPIRo, S. I., \& GoRDON, P. (1971). Contemporary norms of word and phonetic frequencies. Journal of Verbal Learning \& Verbal Behavior, 10, 92-94.

Shoben, E. J. (1982). Semantic and lexical decisions. In C. R. Puff (Ed.), Handbook of research methods in human memory and cognition. New York: Academic Press.

TAFT, M. (1979). Recognition of affixed words and the frequency effect. Memory \& Cognition, 7, 263-272.

TEMPLE, C. M. (1984). Surface dyslexia in a child with epilepsy. Neuropsychologia, 22, 569-576.

THORNDIKE, E. L., \& LORGE, I. (1944). The teacher's word book of 30,000 words. New York: Teachers College Press

Toglia, M. P., \& BatTiG, W. F. (1978). Handbook of semantic word norms. Hillsdale, NJ: Erlbaum.

Webster's new collegiate dictionary. (1977). Springfield, MA: Merriam.

WHITFORD, H. C. (1966). A dictionary of American homophones and homographs. New York: Teachers College Press.

WinShel, S. A., \& Glucksberg, S. (1985, November). Between ewe, $m e$ and the lambpost: Phonological recoding during reading. Paper presented at the meeting of the Psychonomic Society, Boston, MA.

\section{NOTES}

1. A complete list of English homophones, including these rare words, is available from the author.

2. In order to obtain ratings for certain homophonic triplets, some words were included on more than one list to balance the number of words on each questionnaire form.

3. These instructions are based loosely on those used by Gernsbacher (1982) in her collection of "experiential familiarity" ratings of lowfrequency words. Although Gernsbacher used the terms "very familiar" and "very unfamiliar" as polar opposites, the terms "very common" and "very uncommon" were used here because pilot work suggested that the term "familiar" produced ceiling effects with this set of words for this subject population.

4. Judging from the responses of the subjects, it seems that, when reading, most people are entirely unaware of the homophonic nature of homophones. In contrast, people often mistakenly use the homophone of an intended word during writing (e.g., writing "would" for "wood"). Why this should be the case is not clear, although the phenomenon has been noted by others (e.g., Henderson, 1982).

5. This group originally had 15 words, but it was discovered that one of the words had been erroneously included in this range. The data from this word have been deleted from the analyses that are reported elsewhere in this paper. 
Appendix A

Corpus of Homophonic Words

\begin{tabular}{|c|c|c|c|c|c|c|c|}
\hline Word & $\begin{array}{c}\text { Mean } \\
\text { Familiarity }\end{array}$ & $S D$ & $\begin{array}{c}\text { K \& F } \\
\text { Frequency }\end{array}$ & Word & $\begin{array}{c}\text { Mean } \\
\text { Familiarity }\end{array}$ & $S D$ & $\begin{array}{c}\mathrm{K} \& \mathrm{~F} \\
\text { Frequency }\end{array}$ \\
\hline Abel & 2.27 & 1.58 & 20 & able & 6.60 & 0.51 & 216 \\
\hline acts & 5.07 & 1.10 & 39 & $\mathrm{ax}$ & 3.93 & 1.75 & 6 \\
\hline $\mathrm{ad}$ & 4.60 & 2.06 & 11 & add & 6.20 & 0.94 & 88 \\
\hline adieu & 2.20 & 1.01 & 1 & ado & 1.93 & 1.10 & 4 \\
\hline adolescence & 5.40 & 1.24 & 10 & adolescents & 5.13 & 0.92 & 7 \\
\hline affluent & 3.93 & 1.44 & 2 & effluent $\S$ & 1.87 & 1.19 & 18 \\
\hline aid & 5.47 & 1.25 & 130 & aide & 4.20 & 1.15 & 9 \\
\hline air & 6.53 & 0.52 & 257 & ere & 1.67 & 1.29 & 1 \\
\hline err & 3.47 & 1.19 & 1 & heir & 3.73 & 1.83 & 7 \\
\hline aisle & 4.40 & 1.64 & 6 & isle & 3.20 & 1.74 & 5 \\
\hline allowed & 5.33 & 1.50 & 86 & aloud & 5.13 & 1.36 & 13 \\
\hline altar & 4.67 & 1.59 & 5 & alter & 4.33 & 1.05 & 15 \\
\hline an & 7.00 & 0.00 & 3747 & Ann & 4.73 & 2.05 & 29 \\
\hline ant & 5.07 & 1.83 & 6 & aunt & 5.60 & 1.06 & 22 \\
\hline ante & 2.73 & 1.28 & 3 & auntie & 3.93 & 1.91 & 3 \\
\hline are $\S$ & 6.67 & 1.29 & 4393 & hour & 6.67 & 0.49 & 144 \\
\hline ourt & 6.87 & 0.43 & 1252 & & & & \\
\hline armoire & 1.67 & 0.72 & 1 & armor & 3.73 & 1.39 & 4 \\
\hline ate $\S$ & 6.60 & 0.74 & 16 & eight & 6.60 & 0.83 & 104 \\
\hline aw & 3.33 & 2.38 & 3 & awe & 3.93 & 1.39 & 5 \\
\hline awful & 5.87 & 1.06 & 17 & offal & 1.47 & 0.74 & 1 \\
\hline bad & 6.93 & 0.26 & 142 & bade 拉 & 2.37 & 1.27 & 1 \\
\hline bade $† \ddagger$ & 2.37 & 1.27 & 1 & bayed & 1.73 & 1.33 & 3 \\
\hline bail & 4.40 & 1.06 & 7 & bale & 3.27 & 1.67 & 5 \\
\hline bald & 4.93 & 1.22 & 5 & bawled & 3.60 & 1.84 & 2 \\
\hline band & 5.40 & 1.30 & 53 & banned & 4.67 & 1.29 & 2 \\
\hline bard & 1.60 & 0.83 & 3 & barred & 3.33 & 1.23 & 8 \\
\hline bare & 4.73 & 1.10 & 29 & bear & 5.40 & 1.35 & 57 \\
\hline baron & 3.80 & 1.08 & 2 & barren & 3.73 & 1.22 & 7 \\
\hline base & 4.73 & 1.44 & 91 & bass $* \S$ & 3.80 & 1.70 & 16 \\
\hline bay & 5.13 & 0.92 & 57 & bey & 1.33 & 0.49 & 6 \\
\hline bazaar & 2.67 & 0.90 & 7 & bizarre & 5.00 & 1.36 & 7 \\
\hline be & 6.53 & 0.74 & 6377 & bee & 5.47 & 1.60 & 11 \\
\hline beach & 5.67 & 0.98 & 61 & beech & 2.87 & 1.60 & 6 \\
\hline beau & 2.73 & 1.03 & 2 & bow* $\ddagger$ & 4.63 & 1.50 & 15 \\
\hline been & 6.80 & 0.56 & 2472 & Ben & 3.80 & 1.42 & 21 \\
\hline bel & 1.60 & 1.35 & 4 & bell & 5.27 & 1.33 & 18 \\
\hline berry & 4.80 & 1.74 & 9 & bury & 4.93 & 1.16 & 6 \\
\hline berth & 2.53 & 1.13 & 4 & birth & 5.27 & 1.33 & 66 \\
\hline billed & 5.13 & 1.51 & 3 & build & 6.20 & 0.77 & 86 \\
\hline blew & 4.80 & 1.61 & 12 & blue & 6.67 & 0.62 & 143 \\
\hline bloc & 2.80 & 1.32 & 10 & block & 5.20 & 1.37 & 66 \\
\hline boar & 2.73 & 1.53 & 1 & bore & 4.80 & 1.37 & 24 \\
\hline board & 5.80 & 1.08 & 239 & bored & 6.00 & 1.13 & 14 \\
\hline boarder & 4.13 & 1.25 & 1 & border & 5.40 & 1.24 & 20 \\
\hline bolder & 3.80 & 1.32 & 2 & boulder & 4.67 & 1.68 & 10 \\
\hline boos & 2.73 & 1.94 & 2 & booze & 5.00 & 1.69 & 4 \\
\hline born & 5.73 & 0.88 & 113 & borne & 2.53 & 1.51 & 8 \\
\hline borough & 3.40 & 1.40 & 5 & burrow & 3.67 & 1.54 & 4 \\
\hline bough & 2.67 & 1.40 & 2 & bow* & 4.63 & 1.50 & 15 \\
\hline brake & 5.20 & 1.37 & 2 & break & 6.33 & 0.98 & 88 \\
\hline bread $\S$ & 6.73 & 0.46 & 41 & bred & 3.14 & 1.46 & 1 \\
\hline brewed & 4.07 & 1.22 & 1 & brood & 3.47 & 1.46 & 9 \\
\hline bridal & 4.87 & 1.46 & 2 & bridle & 3.20 & 1.15 & 1 \\
\hline bus $\S$ & 6.33 & 0.90 & 34 & buss & 1.47 & 0.74 & 1 \\
\hline but & 6.87 & 0.52 & 4381 & butt & 4.53 & 1.25 & 12 \\
\hline buy & 6.53 & 0.52 & 70 & by & 6.93 & 0.26 & 5305 \\
\hline cache & 1.87 & 0.99 & 1 & $\operatorname{cash} \S$ & 6.40 & 0.83 & 36 \\
\hline Cain & 2.47 & 1.68 & 2 & cane & 4.60 & 1.59 & 12 \\
\hline
\end{tabular}


APPENDIX A (Continued)

\begin{tabular}{|c|c|c|c|c|c|c|c|}
\hline Word & $\begin{array}{c}\text { Mean } \\
\text { Familiarity }\end{array}$ & $S D$ & $\begin{array}{c}\text { K \& F } \\
\text { Frequency }\end{array}$ & Word & $\begin{array}{c}\text { Mean } \\
\text { Familiarity }\end{array}$ & $S D \quad \mathrm{~F}$ & $\begin{array}{c}\text { K \& F } \\
\text { Frequency }\end{array}$ \\
\hline cannon & 3.67 & 1.54 & 7 & canon & 3.00 & 1.41 & 5 \\
\hline cant & 2.80 & 1.97 & 1 & can't & 6.73 & 0.46 & 169 \\
\hline canter & 2.67 & 1.40 & 1 & cantor & 2.53 & 1.60 & 2 \\
\hline canvas & 4.67 & 1.29 & 19 & canvass & 2.93 & 1.03 & 3 \\
\hline capital & 4.67 & 1.35 & 85 & capitol & 4.20 & 1.42 & 22 \\
\hline carol & 4.60 & 1.64 & 2 & carrel & 3.20 & 1.82 & 1 \\
\hline cast & 4.93 & 1.33 & 45 & caste & 2.13 & 1.19 & 3 \\
\hline ceil & 1.33 & 0.49 & 1 & seal & 5.13 & 1.13 & 17 \\
\hline cell & 4.67 & 1.40 & 65 & sell§ & 6.53 & 0.74 & 41 \\
\hline cellar & 4.80 & 1.52 & 26 & seller & 5.73 & 1.33 & 6 \\
\hline cent & 6.33 & 0.98 & 158 & sent & 6.40 & 0.83 & 145 \\
\hline cents & 5.79 & 1.53 & 25 & sense & 6.13 & 1.06 & 311 \\
\hline cereal & 5.93 & 1.10 & 17 & serial & 4.07 & 1.39 & 7 \\
\hline cession & 2.00 & 0.76 & 1 & session & 4.67 & 1.40 & 80 \\
\hline chance & 6.07 & 0.88 & 131 & chants & 3.67 & 1.50 & 3 \\
\hline chantey & 1.73 & 1.67 & 2 & shanty & 2.60 & 1.68 & 3 \\
\hline chic & 4.47 & 1.46 & 7 & sheik $\nmid \ddagger$ & 2.60 & 1.43 & 4 \\
\hline chili & 4.53 & 1.51 & 6 & chilly & 5.53 & 1.30 & 5 \\
\hline choral & 3.13 & 1.55 & 2 & coral & 2.67 & 1.23 & 5 \\
\hline chorale & 3.07 & 1.03 & 1 & corral & 3.20 & 1.26 & 5 \\
\hline chord & 4.13 & 1.85 & 7 & cord & 4.43 & 1.28 & 6 \\
\hline chute & 2.13 & 1.64 & 2 & shoot & 4.60 & 1.45 & 27 \\
\hline Claude & 2.47 & 1.36 & 11 & clawed & 4.67 & 1.50 & 2 \\
\hline clause & 3.47 & 1.25 & 9 & claws & 4.93 & 1.49 & 3 \\
\hline click & 4.67 & 1.45 & 2 & clique & 4.13 & 1.51 & 2 \\
\hline close* & 6.33 & 0.90 & 234 & clothes & 6.73 & 0.59 & 89 \\
\hline clucks & 2.80 & 1.42 & 2 & Klux & 2.87 & 1.85 & 3 \\
\hline coal & 4.67 & 1.45 & 32 & cole & 1.53 & 0.92 & 1 \\
\hline coarse & 4.40 & 1.30 & 10 & course & 6.13 & 1.41 & 465 \\
\hline $\operatorname{coax}$ & 4.07 & 1.58 & 1 & Cokes & 6.50 & 0.52 & 1 \\
\hline colonel & 4.20 & 1.26 & 37 & kernel & 4.73 & 1.28 & 3 \\
\hline complement & 4.27 & 1.67 & 21 & compliment & 5.67 & 0.90 & 3 \\
\hline confirmation & 4.73 & 1.33 & 7 & conformation & 2.80 & 1.52 & 3 \\
\hline coop & 2.93 & 1.62 & 3 & coupe & 2.07 & 1.33 & 2 \\
\hline core & 4.73 & 1.28 & 37 & corps $\S$ & 3.20 & 1.15 & 109 \\
\hline correspondence & 4.33 & 1.35 & 25 & correspondents & 4.67 & 1.18 & 5 \\
\hline council & 4.93 & 1.28 & 103 & counsel & 4.00 & 1.46 & 17 \\
\hline cousin & 4.60 & 1.40 & 51 & cozen & 1.33 & 1.29 & 1 \\
\hline creak & 4.60 & 1.50 & 1 & creek $\uparrow$ & 4.20 & 1.01 & 14 \\
\hline crewel & 1.93 & 1.33 & 2 & cruel & 5.07 & 1.22 & 15 \\
\hline currant & 2.60 & 1.30 & 1 & current & 5.43 & 1.22 & 104 \\
\hline curt§ & 2.33 & 1.23 & 32 & Kurt & 3.20 & 1.21 & 1 \\
\hline dam & 4.87 & 1.06 & 5 & damn & 6.07 & 0.96 & 34 \\
\hline dear & 5.33 & 1.35 & 54 & deer & 5.07 & 1.39 & 13 \\
\hline dependence & 4.53 & 1.25 & 12 & dependents & 3.40 & 1.40 & 2 \\
\hline descent & 3.87 & 1.81 & 11 & dissent & 4.07 & 1.22 & 5 \\
\hline desert & 5.00 & 1.41 & 21 & dessert & 5.93 & 0.96 & 7 \\
\hline dew & 3.73 & 1.53 & 3 & due & 5.60 & 0.83 & 142 \\
\hline dire & 3.20 & 1.86 & 1 & dyer & 1.27 & 0.46 & 3 \\
\hline disc & 5.14 & 1.35 & 6 & disk & 5.33 & 1.50 & 25 \\
\hline discreet & 4.67 & 1.18 & 3 & discrete & 4.07 & 1.49 & 7 \\
\hline doe & 3.60 & 1.55 & 1 & dough & 4.60 & 1.18 & 13 \\
\hline doc & 3.80 & 2.08 & 20 & dock & 4.53 & 0.99 & 8 \\
\hline done & 6.53 & 0.64 & 320 & dun & 1.40 & 1.06 & 1 \\
\hline Doug & 5.07 & 1.67 & 1 & dug & 4.53 & 1.55 & 15 \\
\hline dread & 4.13 & 1.64 & 9 & Dred & 1.80 & 1.78 & 1 \\
\hline dual & 4.13 & 1.60 & 9 & duel & 3.07 & 0.70 & 5 \\
\hline ducked & 4.87 & 1.51 & 5 & duct & 3.47 & 1.25 & 1 \\
\hline earn & 5.67 & 1.23 & 16 & urn & 2.27 & 1.16 & 2 \\
\hline earnest & 4.13 & 1.36 & 18 & Ernest & 2.07 & 1.03 & 10 \\
\hline
\end{tabular}


APPENDIX A (Continued)

\begin{tabular}{|c|c|c|c|c|c|c|c|}
\hline Word & $\begin{array}{c}\text { Mean } \\
\text { Familiarity }\end{array}$ & $S D$ & $\begin{array}{l}\text { K \& F } \\
\text { Frequency }\end{array}$ & Word & $\begin{array}{c}\text { Mean } \\
\text { Familiarity }\end{array}$ & $S D$ & $\begin{array}{c}\text { K \& F } \\
\text { Frequency }\end{array}$ \\
\hline eerie & 3.27 & 0.80 & 2 & Erie & 2.87 & 1.73 & 2 \\
\hline elicit & 3.40 & 1.45 & 3 & illicit & 3.47 & 1.46 & 3 \\
\hline ensure & 3.53 & 1.68 & 8 & insure & 4.60 & 1.12 & 24 \\
\hline ewe & 2.67 & 1.40 & 1 & you & 7.00 & 0.00 & 3286 \\
\hline exercise & 6.20 & 0.94 & 58 & exorcise & 2.27 & 0.96 & 1 \\
\hline eye & 6.33 & 0.90 & 122 & I & 7.00 & 0.00 & 5173 \\
\hline faint & 5.13 & 1.25 & 25 & feint & 2.13 & 1.36 & 2 \\
\hline fair & 6.00 & 0.93 & 77 & fare & 3.93 & 1.58 & 7 \\
\hline fairy & 4.27 & 1.33 & 4 & ferry & 4.33 & 1.29 & 11 \\
\hline fate & 5.13 & 1.25 & 33 & fete & 2.13 & 1.13 & 3 \\
\hline faze & 3.87 & 1.85 & 1 & phase & 4.13 & 1.41 & 72 \\
\hline feat & 3.67 & 1.23 & 6 & feet & 6.60 & 0.74 & 283 \\
\hline fill & 5.87 & 0.99 & 50 & Phil & 4.33 & 1.80 & 65 \\
\hline fillip & 1.07 & 0.26 & 1 & Philip & 4.40 & 2.03 & 21 \\
\hline fin & 4.53 & 1.36 & 2 & Finn & 2.07 & 1.39 & 1 \\
\hline find & 6.20 & 0.94 & 399 & fined & 4.33 & 1.40 & 4 \\
\hline finish§ & 6.53 & 0.52 & 39 & Finnish & 2.47 & 1.69 & 1 \\
\hline fir & 3.00 & 1.20 & 2 & fur & 5.47 & 1.51 & 13 \\
\hline flair & 3.87 & 1.36 & 8 & flare & 3.47 & 1.41 & 3 \\
\hline flea & 4.20 & 1.52 & 2 & flee & 4.67 & 1.50 & 1 \\
\hline flew & 5.40 & 1.40 & 27 & flu & 4.87 & 1.41 & 8 \\
\hline floe & 1.20 & 0.41 & 1 & flow & 4.60 & 1.40 & 67 \\
\hline flour & 5.60 & 0.99 & 8 & flower & 6.13 & 1.13 & 23 \\
\hline for & 7.00 & 0.00 & 9489 & four & 5.87 & 1.60 & 359 \\
\hline fort§ & 3.07 & 1.49 & 55 & forte & 2.87 & 1.73 & 6 \\
\hline forth§ & 3.53 & 1.19 & 71 & fourth & 6.60 & 0.91 & 74 \\
\hline foul & 4.64 & 1.86 & 4 & fowl & 4.07 & 1.53 & 1 \\
\hline franc & 2.27 & 1.22 & 1 & frank & 4.20 & 1.42 & 68 \\
\hline freeze & 6.20 & 0.86 & 6 & frieze & 1.53 & 0.83 & 13 \\
\hline gage & 3.60 & 1.72 & 4 & gauge & 3.53 & 1.06 & 12 \\
\hline gait & 3.27 & 1.44 & 8 & gate & 4.67 & 1.05 & 37 \\
\hline gall & 3.20 & 1.52 & 7 & Gaul & 2.20 & 1.47 & 1 \\
\hline gene & 3.53 & 1.06 & 9 & jean & 6.07 & 0.88 & 23 \\
\hline gild & 1.93 & 1.10 & 1 & guild & 2.93 & 1.28 & 7 \\
\hline gilt & 1.47 & 0.64 & 3 & guilt & 5.20 & 1.21 & 33 \\
\hline grade $\S$ & 6.47 & 0.92 & 35 & grayed & 3.67 & 1.54 & 1 \\
\hline graft & 2.87 & 1.77 & 1 & graphed & 4.13 & 1.06 & 1 \\
\hline grate & 3.67 & 1.29 & 3 & great§ & 6.73 & 0.46 & 665 \\
\hline grease & 5.27 & 1.33 & 9 & Greece & 4.47 & 1.25 & 16 \\
\hline grill & 4.80 & 1.37 & 12 & grille & 2.27 & 1.22 & 3 \\
\hline grisly & 3.53 & 1.30 & 2 & grizzly & 3.60 & 1.35 & 1 \\
\hline groan & 4.60 & 1.68 & 1 & grown & 5.20 & 1.15 & 43 \\
\hline guessed & 5.67 & 1.29 & 15 & guest & 5.87 & 0.83 & 39 \\
\hline guise & 2.60 & 1.30 & 6 & guys $\S$ & 6.67 & 0.62 & 20 \\
\hline gym & 5.80 & 1.08 & 2 & Jim & 6.13 & 1.36 & 36 \\
\hline hail & 3.67 & 1.99 & 10 & hale & 1.80 & 0.77 & 2 \\
\hline hair & 6.33 & 1.05 & 148 & hare & 2.87 & 1.64 & 1 \\
\hline hairy & 5.93 & 1.16 & 5 & Harry & 3.53 & 1.85 & 35 \\
\hline hall & 6.40 & 0.63 & 152 & haul & 4.60 & 1.80 & 5 \\
\hline handsome & 5.93 & 1.03 & 40 & hansom & 1.53 & 0.83 & 1 \\
\hline Harold & 3.33 & 1.54 & 4 & herald & 3.20 & 1.61 & 11 \\
\hline hart & 1.40 & 0.63 & 13 & heart & 6.33 & 0.82 & 173 \\
\hline hay & 3.93 & 1.28 & 19 & hey & 5.87 & 1.77 & 15 \\
\hline hays & 1.73 & 1.33 & 6 & haze & 4.07 & 1.75 & 7 \\
\hline heal & 4.40 & 1.40 & 2 & heel & 5.07 & 1.22 & 9 \\
\hline he'll † & 6.36 & 1.15 & 31 & & & & \\
\hline hear & 6.67 & 0.62 & 153 & here§ & 6.80 & 0.41 & 750 \\
\hline heard & 6.40 & 0.74 & 247 & herd $\S$ & 3.67 & 1.68 & 22 \\
\hline he'd & 6.47 & 0.83 & 98 & heed & 3.33 & 1.50 & 8 \\
\hline
\end{tabular}


APPENDIX A (Continued)

\begin{tabular}{|c|c|c|c|c|c|c|c|}
\hline Word & $\begin{array}{c}\text { Mean } \\
\text { Familiarity }\end{array}$ & $S D$ & $\begin{array}{c}\mathrm{K} \& \mathrm{~F} \\
\text { Frequency }\end{array}$ & Word & $\begin{array}{c}\text { Mean } \\
\text { Familiarity }\end{array}$ & $S D \quad \mathrm{~F}$ & $\begin{array}{c}\text { K \& F } \\
\text { Frequency }\end{array}$ \\
\hline he'llt & 6.36 & 1.15 & 31 & hill & 6.53 & 0.83 & 72 \\
\hline heroin & 3.47 & 1.85 & 2 & heroine & 3.33 & 1.29 & 5 \\
\hline hertz & 3.00 & 1.81 & 1 & hurts & 6.40 & 0.63 & 4 \\
\hline hi & 6.93 & 0.26 & 6 & high§ & 6.40 & 0.74 & 497 \\
\hline higher & 6.00 & 1.13 & 160 & hire & 5.13 & 1.46 & 15 \\
\hline him & 7.00 & 0.00 & 2619 & hymn & 4.60 & 1.68 & 3 \\
\hline hoarse & 4.20 & 1.37 & 5 & horse & 6.07 & 0.88 & 117 \\
\hline hoes & 2.60 & 1.12 & 1 & hose & 5.40 & 1.50 & 9 \\
\hline hold & 6.13 & 0.92 & 169 & holed & 2.67 & 1.68 & 1 \\
\hline hole & 5.40 & 1.45 & 58 & whole & 5.87 & 0.99 & 309 \\
\hline holy & 5.60 & 1.30 & 49 & wholly & 4.00 & 1.46 & 24 \\
\hline hoop & 4.53 & 1.13 & 3 & whoop & 2.80 & 0.68 & 1 \\
\hline hue & 3.07 & 1.03 & 1 & Hugh & 3.53 & 1.85 & 9 \\
\hline idle & 4.67 & 1.45 & 13 & idol & 4.13 & 1.13 & 7 \\
\hline in & 7.00 & 0.00 & 21341 & inn & 4.27 & 1.33 & 9 \\
\hline incidence & 4.00 & 1.00 & 7 & incidents & 4.13 & 1.46 & 11 \\
\hline innocence & 5.27 & 1.03 & 28 & innocents & 3.13 & 1.51 & 1 \\
\hline its & 7.00 & 0.00 & 1858 & it's & 6.93 & 0.26 & 302 \\
\hline knead & 3.20 & 1.66 & 1 & need & 6.60 & 0.63 & 360 \\
\hline kneel & 4.53 & 1.51 & 5 & Neil & 3.93 & 1.79 & 3 \\
\hline knew & 6.53 & 0.83 & 395 & new & 6.87 & 0.35 & 1635 \\
\hline knight & 3.40 & 1.72 & 18 & night & 6.73 & 0.46 & 411 \\
\hline knob & 4.87 & 1.19 & 2 & nob & 2.80 & 1.61 & 1 \\
\hline knot & 5.67 & 1.45 & 8 & not & 6.93 & 0.26 & 4609 \\
\hline know§ & 6.73 & 0.59 & 683 & no & 7.00 & 0.00 & 2201 \\
\hline knows & 6.67 & 0.49 & 99 & nose & 6.00 & 1.00 & 60 \\
\hline lacks & 5.07 & 0.96 & 6 & $\operatorname{lax}$ & 3.60 & 1.59 & 3 \\
\hline ladder & 5.27 & 1.03 & 19 & latter & 4.20 & 1.66 & 114 \\
\hline lain & 2.73 & 2.05 & 4 & lane & 4.73 & 1.39 & 30 \\
\hline laps & 5.13 & 1.25 & 2 & lapse & 4.13 & 0.99 & 6 \\
\hline lays & 4.33 & 1.76 & 6 & laze & 2.33 & 1.18 & 1 \\
\hline lead* & 6.00 & 1.00 & 129 & led & 5.73 & 0.96 & 132 \\
\hline leader & 5.93 & 1.10 & 74 & lieder & 1.20 & 0.41 & 2 \\
\hline leads* & 5.40 & 1.35 & 33 & Leeds & 1.20 & 0.77 & 1 \\
\hline lean & 4.93 & 1.10 & 20 & lien & 1.40 & 0.74 & 2 \\
\hline leased & 4.13 & 1.60 & 2 & least & 5.87 & 1.06 & 343 \\
\hline lends & 5.80 & 1.32 & 4 & lens & 4.93 & 0.80 & 12 \\
\hline Les & 2.47 & 1.85 & 3 & less & 5.87 & 1.51 & 438 \\
\hline lessen & 4.47 & 1.36 & 5 & lesson & 5.93 & 0.96 & 29 \\
\hline levee & 1.80 & 1.37 & 1 & levy & 2.33 & 1.45 & 7 \\
\hline lieu & 3.60 & 1.76 & 5 & Lou & 3.13 & 1.30 & 13 \\
\hline $\operatorname{lo\S }$ & 1.60 & 0.63 & 22 & low & 6.07 & 0.96 & 174 \\
\hline loan & 5.07 & 1.33 & 46 & lone & 4.00 & 1.46 & 8 \\
\hline loot & 3.73 & 1.33 & 3 & lute & 1.80 & 1.32 & 1 \\
\hline lumbar & 2.13 & 1.51 & 1 & lumber & 4.27 & 1.28 & 35 \\
\hline $\mathrm{ma}$ & 4.67 & 2.13 & 19 & maw & 1.53 & 0.74 & 2 \\
\hline made§ & 6.80 & 0.41 & 1125 & maid & 4.93 & 1.28 & 31 \\
\hline Mae & 2.00 & 1.00 & 16 & may & 6.87 & 0.35 & 1400 \\
\hline magnate & 2.80 & 1.47 & 1 & magnet & 4.53 & 1.06 & 3 \\
\hline mail§ & 6.33 & 0.90 & 47 & male§ & 6.33 & 0.82 & 37 \\
\hline main & 5.87 & 1.25 & 119 & Maine & 4.00 & 1.51 & 9 \\
\hline mall & 5.73 & 1.16 & 3 & moll & 1.40 & 0.51 & 5 \\
\hline manner & 4.60 & 1.50 & 124 & manor & 2.80 & 1.42 & 5 \\
\hline mantel & 3.07 & 1.62 & 3 & mantle§ & 3.27 & 1.53 & 48 \\
\hline mare & 2.87 & 1.41 & 16 & mayor & 4.47 & 1.46 & 38 \\
\hline marks & 4.93 & 1.39 & 28 & Marx & 3.60 & 1.59 & 8 \\
\hline marry & 5.40 & 1.30 & 18 & Mary & 5.60 & 1.68 & 88 \\
\hline massed & 3.13 & 1.13 & 2 & mast & 3.33 & 1.45 & 6 \\
\hline mat & 4.40 & 1.59 & 5 & Matt & 4.33 & 1.68 & 3 \\
\hline
\end{tabular}


APPENDIX A (Continued)

\begin{tabular}{|c|c|c|c|c|c|c|c|}
\hline Word & $\begin{array}{c}\text { Mean } \\
\text { Familiarity }\end{array}$ & $S D$ & $\begin{array}{c}\text { K \& F } \\
\text { Frequency }\end{array}$ & Word & $\begin{array}{c}\text { Mean } \\
\text { Familiarity }\end{array}$ & $S D$ & $\begin{array}{c}\text { K \& F } \\
\text { Frequency }\end{array}$ \\
\hline me & 6.93 & 0.26 & 1181 & $\mathrm{mi}$ & 1.07 & 0.26 & 3 \\
\hline mean & 6.07 & 0.88 & 199 & mien & 1.47 & 1.06 & 1 \\
\hline meat§ & 6.33 & 0.90 & 45 & meet & 6.00 & 0.93 & 148 \\
\hline medal & 4.47 & 1.77 & 7 & meddle & 3.33 & 1.50 & 1 \\
\hline metal & 5.60 & 1.35 & 61 & mettle & 2.60 & 0.99 & 2 \\
\hline might§ & 6.33 & 1.11 & 672 & mite & 2.73 & 0.96 & 1 \\
\hline mil & 1.60 & 0.74 & 1 & mill & 4.47 & 1.25 & 11 \\
\hline mind & 6.27 & 0.80 & 325 & mined & 4.07 & 1.39 & 3 \\
\hline miner & 3.47 & 1.46 & 1 & minor & 5.27 & 1.44 & 58 \\
\hline missed & 6.20 & 1.15 & 40 & mist & 4.93 & 1.03 & 14 \\
\hline misses & 5.07 & 1.67 & 5 & Mrs. & 6.60 & 1.06 & 534 \\
\hline mode§ & 3.53 & 1.55 & 21 & mowed & 3.67 & 1.23 & 1 \\
\hline $\operatorname{mood}$ & 5.47 & 0.92 & 37 & mooed & 2.47 & 1.41 & 1 \\
\hline moral & 5.67 & 1.23 & 142 & morel & 1.20 & 0.56 & 1 \\
\hline mustard & 5.13 & 1.25 & 20 & mustered & 3.40 & 1.46 & 1 \\
\hline naval & 4.13 & 1.73 & 33 & navel & 3.40 & 1.12 & 2 \\
\hline none & 6.33 & 0.90 & 108 & nun & 3.93 & 1.28 & 2 \\
\hline oh & 6.73 & 0.46 & 119 & owe & 5.53 & 1.77 & 10 \\
\hline or & 6.87 & 0.35 & 4207 & ore & 3.27 & 1.58 & 3 \\
\hline one & 7.00 & 0.00 & 3292 & won & 6.20 & 0.68 & 68 \\
\hline pa & 4.27 & 2.34 & 32 & paw & 4.60 & 1.99 & 3 \\
\hline paced & 4.00 & 1.20 & 11 & paste & 3.80 & 1.93 & 10 \\
\hline packed & 5.60 & 1.59 & 19 & pact & 3.27 & 0.70 & 5 \\
\hline pail & 4.47 & 1.55 & 4 & pale & 4.33 & 1.54 & 58 \\
\hline pain & 6.27 & 0.80 & 88 & pane & 4.07 & 1.75 & 3 \\
\hline pair & 5.53 & 1.06 & 50 & pear & 4.93 & 1.75 & 6 \\
\hline palate & 3.47 & 1.55 & 2 & palette & 2.20 & 1.01 & 5 \\
\hline pall & 1.53 & 0.92 & 4 & Paul & 5.20 & 1.61 & 38 \\
\hline parry & 1.47 & 0.64 & 1 & Perry & 2.67 & 1.35 & 8 \\
\hline passed & 6.27 & 1.16 & 157 & past & 6.13 & 0.74 & 281 \\
\hline patience & 5.40 & 0.99 & 22 & patients & 5.47 & 1.30 & 36 \\
\hline Patti & 3.33 & 1.50 & 1 & patty & 3.13 & 1.77 & 1 \\
\hline pause & 5.73 & 1.03 & 21 & paws & 4.40 & 1.30 & 3 \\
\hline peace & 6.13 & 0.83 & 198 & piece & 6.20 & 0.86 & 129 \\
\hline peak & 4.93 & 1.33 & 16 & pique & 1.64 & 0.84 & 2 \\
\hline peal & 3.47 & 2.20 & 1 & peel & 4.27 & 1.44 & 3 \\
\hline pedal & 4.53 & 1.36 & 4 & peddle & 3.27 & 1.53 & 1 \\
\hline peer & 4.47 & 1.92 & 8 & pier & 3.13 & 1.46 & 3 \\
\hline pi & 2.47 & 1.06 & 3 & pie & 6.00 & 1.07 & 14 \\
\hline pidgin & 1.33 & 0.62 & 2 & pigeon & 4.53 & 1.19 & 3 \\
\hline plain & 6.00 & 0.93 & 48 & plane & 6.20 & 0.77 & 114 \\
\hline pleas & 3.20 & 1.26 & 3 & please $\$$ & 6.80 & 0.56 & 62 \\
\hline plum & 4.21 & 1.53 & 1 & plumb & 2.73 & 1.79 & 5 \\
\hline pole & 4.93 & 1.33 & 18 & poll & 4.20 & 1.42 & 9 \\
\hline poor & 6.27 & 0.96 & 113 & pour & 5.80 & 1.15 & 9 \\
\hline populace & 2.60 & 1.12 & 4 & populous & 3.33 & 1.54 & 5 \\
\hline pray & 5.13 & 1.55 & 12 & prey & 3.73 & 1.49 & 7 \\
\hline presence & 4.87 & 1.13 & 76 & presents & 6.13 & 1.06 & 33 \\
\hline prince & 4.87 & 1.36 & 33 & prints & 4.53 & 1.88 & 10 \\
\hline principal & 4.40 & 1.64 & 92 & principle & 4.60 & 1.30 & 109 \\
\hline profit & 5.27 & 1.22 & 28 & prophet & 3.67 & 1.59 & 5 \\
\hline pros & 5.27 & 1.62 & 2 & prose & 3.93 & 1.22 & 14 \\
\hline psi & 1.60 & 0.92 & 1 & sigh & 5.73 & 0.96 & 11 \\
\hline quarts & 4.47 & 0.99 & 1 & quartz & 3.20 & 1.82 & 1 \\
\hline rack & 5.47 & 1.06 & 9 & wrack & 2.47 & 1.13 & 1 \\
\hline rain & 6.60 & 0.51 & 70 & reign & 3.40 & 1.24 & 7 \\
\hline raise & 6.00 & 1.46 & 52 & rays & 5.07 & 1.03 & 9 \\
\hline raiser & 2.07 & 1.44 & 1 & razor & 5.80 & 1.21 & 15 \\
\hline rap & 5.20 & 1.08 & 2 & wrap & 5.47 & 1.30 & 5 \\
\hline rapped & 2.73 & 1.44 & 4 & rapt & 2.67 & 1.80 & 1 \\
\hline
\end{tabular}


APPENDIX A (Continued)

\begin{tabular}{|c|c|c|c|c|c|c|c|}
\hline Word & $\begin{array}{c}\text { Mean } \\
\text { Familiarity }\end{array}$ & $S D \quad \mathrm{~F}$ & $\begin{array}{c}\text { K \& F } \\
\text { Frequency }\end{array}$ & Word & $\begin{array}{c}\text { Mean } \\
\text { Familiarity }\end{array}$ & $S D \quad \mathrm{~F}$ & $\begin{array}{c}\text { K \& F } \\
\text { Frequency }\end{array}$ \\
\hline ray & 4.40 & 1.50 & 19 & re & 1.87 & 1.51 & 2 \\
\hline read* $\ddagger$ & 6.63 & 0.67 & 173 & red & 6.93 & 0.26 & 197 \\
\hline $\operatorname{read}^{*} \ddagger$ & 6.63 & 0.67 & 173 & reed & 3.00 & 1.13 & 5 \\
\hline real & 6.53 & 0.64 & 260 & reel & 4.33 & 1.45 & 2 \\
\hline reek & 3.73 & 1.62 & 2 & wreak & 3.00 & 1.41 & 1 \\
\hline residence & 5.20 & 1.08 & 29 & residents & 5.07 & 1.33 & 20 \\
\hline rest & 6.60 & 0.51 & 163 & wrest & 2.07 & 0.88 & 1 \\
\hline retch & 2.33 & 1.29 & 1 & wretch & 3.73 & 1.75 & 1 \\
\hline rheum & 1.33 & 0.62 & 1 & room & 6.47 & 0.64 & 383 \\
\hline right§ & 6.67 & 0.82 & 613 & rite & 3.00 & 1.25 & 8 \\
\hline wright§ & 1.93 & 1.39 & 46 & write & 6.73 & 0.46 & 106 \\
\hline ring & 5.57 & 1.22 & 47 & wring & 3.93 & 1.71 & 2 \\
\hline road & 6.53 & 0.74 & 197 & Rhode & 2.07 & 1.22 & 105 \\
\hline rode & 5.80 & 1.15 & 40 & rowed & 4.13 & 1.77 & 2 \\
\hline roam & 3.53 & 1.46 & 6 & Rome & 4.13 & 1.51 & 70 \\
\hline roe & 1.80 & 1.01 & 1 & row* & 5.60 & 1.12 & 35 \\
\hline role & 4.93 & 1.10 & 104 & roll & 5.87 & 0.74 & 35 \\
\hline root & 4.80 & 1.08 & 30 & route† & 4.67 & 1.68 & 43 \\
\hline rose & 5.80 & 1.21 & 86 & rows* $\ddagger$ & 5.47 & 1.25 & 16 \\
\hline rouse & 3.00 & 1.81 & 2 & rows* $\ddagger$ & 5.47 & 1.25 & 16 \\
\hline Russell & 3.73 & 2.34 & 12 & rustle & 3.93 & 1.44 & 4 \\
\hline rye & 4.14 & 1.70 & 4 & wry & 3.07 & 1.58 & 5 \\
\hline sacks & 3.47 & 1.46 & 1 & sax & 3.73 & 1.58 & 6 \\
\hline sail & 4.93 & 1.33 & 12 & sale & 5.73 & 0.88 & 44 \\
\hline saver & 2.73 & 1.44 & 1 & savor & 2.87 & 1.13 & 1 \\
\hline scene & 5.07 & 1.53 & 106 & seen & 6.60 & 0.74 & 279 \\
\hline Scot & 2.60 & 2.06 & 1 & Scott & 4.13 & 1.85 & 16 \\
\hline sea & 6.00 & 0.85 & 95 & see & 6.73 & 0.59 & 772 \\
\hline seam & 4.00 & 1.56 & 9 & seem & 6.87 & 0.35 & 229 \\
\hline sects & 3.00 & 1.31 & 2 & sex & 6.73 & 0.80 & 84 \\
\hline sees§ & 6.40 & 1.12 & 36 & seize & 4.07 & 1.28 & 6 \\
\hline serge & 1.60 & 0.83 & 5 & surge & 3.00 & 1.36 & 9 \\
\hline sew & 4.80 & 1.57 & 6 & so & 7.00 & 0.00 & 1984 \\
\hline sewn & 3.53 & 1.13 & 1 & sown & 2.00 & 1.20 & 3 \\
\hline shake & 5.13 & 1.30 & 17 & sheik †丮 & 2.60 & 1.43 & 4 \\
\hline shear§ & 3.13 & 1.06 & 40 & sheer & 3.53 & 1.46 & 15 \\
\hline Shirley & 3.07 & 1.44 & 5 & surely & 5.40 & 1.68 & 47 \\
\hline shone & 3.47 & 1.88 & 5 & shown & 5.93 & 1.10 & 166 \\
\hline sic & 1.80 & 0.86 & 4 & sick§ & 6.60 & 0.74 & 51 \\
\hline side & 6.27 & 0.70 & 380 & sighed & 4.13 & 1.81 & 22 \\
\hline sighs & 4.47 & 1.30 & 1 & size & 6.20 & 1.08 & 138 \\
\hline sight & 5.80 & 0.94 & 86 & site & 4.73 & 1.28 & 64 \\
\hline sign & 6.07 & 1.10 & 94 & sine & 2.60 & 1.72 & 4 \\
\hline Sioux & 1.93 & 1.16 & 8 & sue & 4.73 & 1.39 & 18 \\
\hline sky & 6.27 & 0.80 & 58 & Skye & 1.27 & 0.59 & 1 \\
\hline sleight & 2.53 & 1.30 & 1 & slight & 4.53 & 1.13 & 53 \\
\hline sloe & 1.53 & 0.52 & 2 & slow§ & 6.67 & 0.62 & 60 \\
\hline soared & 3.40 & 1.24 & 4 & sword & 3.40 & 1.72 & 7 \\
\hline sole & 4.07 & 1.10 & 18 & soul & 5.27 & 1.49 & 47 \\
\hline some§ & 6.73 & 0.59 & 1617 & sum & 5.07 & 0.96 & 45 \\
\hline son & 6.47 & 0.92 & 166 & sun & 6.80 & 0.41 & 112 \\
\hline staid & 2.53 & 1.68 & 1 & stayed & 5.60 & 1.35 & 75 \\
\hline stair & 5.40 & 1.35 & 2 & stare & 5.13 & 1.06 & 14 \\
\hline stake & 4.73 & 1.03 & 20 & steak & 5.33 & 1.18 & 10 \\
\hline stationary & 4.93 & 1.58 & 2 & stationery & 5.20 & 0.94 & 2 \\
\hline steal & 5.73 & 1.10 & 5 & steel & 5.80 & 0.94 & 45 \\
\hline straight & 6.13 & 0.83 & 114 & strait & 3.20 & 1.90 & 5 \\
\hline suite & 4.07 & 1.53 & 27 & sweet & 6.27 & 0.80 & 70 \\
\hline tacked & 4.60 & 1.40 & 2 & tact & 5.07 & 1.03 & 6 \\
\hline
\end{tabular}


APPENDIX A (Continued)

\begin{tabular}{|c|c|c|c|c|c|c|c|}
\hline Word & $\begin{array}{c}\text { Mean } \\
\text { Familiarity }\end{array}$ & $S D$ & $\begin{array}{c}\text { K \& F } \\
\text { Frequency }\end{array}$ & Word & $\begin{array}{c}\text { Mean } \\
\text { Familiarity }\end{array}$ & $S D$ & $\begin{array}{c}\text { K \& F } \\
\text { Frequency }\end{array}$ \\
\hline tail & 6.07 & 1.16 & 24 & tale & 5.07 & 1.33 & 21 \\
\hline taught & 5.80 & 1.08 & 50 & taut & 2.93 & 0.70 & 8 \\
\hline tea & 5.73 & 1.22 & 28 & tee & 3.27 & 1.53 & 5 \\
\hline teas & 3.80 & 1.78 & 1 & tease & 5.07 & 1.44 & 6 \\
\hline tempera & 1.73 & 0.80 & 1 & tempura & 2.07 & 1.39 & 0 \\
\hline tense & 5.87 & 0.74 & 15 & tents & 4.80 & 1.32 & 10 \\
\hline Thai & 1.67 & 1.29 & 1 & tie & 5.67 & 1.05 & 23 \\
\hline the & 7.00 & 0.00 & 69971 & thee§ & 1.67 & 0.90 & 17 \\
\hline thees & 1.27 & 0.80 & 1 & these & 6.87 & 0.35 & 1573 \\
\hline their & 6.93 & 0.26 & 2670 & there & 6.93 & 0.26 & 2724 \\
\hline threw & 5.93 & 0.88 & 46 & through§ & 6.60 & 0.63 & 969 \\
\hline throne & 4.27 & 1.53 & 5 & thrown & 5.53 & 0.92 & 40 \\
\hline tide & 4.33 & 1.18 & 11 & tied & 5.60 & 0.91 & 34 \\
\hline tighten & 5.13 & 1.41 & 3 & Titan & 1.87 & 0.99 & 7 \\
\hline timber & 4.40 & 1.40 & 19 & timbre & 2.27 & 0.80 & 2 \\
\hline to & 6.93 & 0.26 & 26149 & two & 6.93 & 0.26 & 1412 \\
\hline toad & 3.80 & 1.66 & 4 & towed & 4.20 & 1.46 & 1 \\
\hline toe & 6.00 & 0.93 & 9 & tow & 4.13 & 1.68 & 1 \\
\hline told & 6.67 & 0.62 & 2 & tolled & 2.67 & 1.40 & 1 \\
\hline tole & 1.73 & 1.33 & 1 & toll & 4.80 & 1.42 & 16 \\
\hline tongue & 5.87 & 1.30 & 35 & tung & 1.27 & 0.59 & 2 \\
\hline tool & 5.73 & 1.22 & 40 & tulle & 1.13 & 0.35 & 1 \\
\hline tracked & 3.67 & 1.64 & 3 & tract & 3.00 & 1.41 & 17 \\
\hline troop & 4.47 & 1.30 & 16 & troupe & 2.80 & 1.52 & 3 \\
\hline vain & 4.13 & 1.77 & 10 & vein & 4.60 & 1.45 & 25 \\
\hline vale & 2.40 & 1.55 & 4 & veil & 3.00 & 1.69 & 8 \\
\hline vary & 5.13 & 0.99 & 34 & very & 7.00 & 0.00 & 796 \\
\hline verses & 4.40 & 1.24 & 9 & versus & 5.27 & 0.80 & 9 \\
\hline vice & 5.13 & 1.19 & 41 & vise & 2.53 & 0.92 & 1 \\
\hline wade & 4.53 & 0.99 & 2 & weighed & 5.27 & 1.33 & 16 \\
\hline wails & 3.67 & 1.84 & 2 & Wales & 3.33 & 1.54 & 10 \\
\hline waist & 5.13 & 0.99 & 11 & waste & 5.73 & 1.22 & 35 \\
\hline wait & 6.07 & 0.88 & 94 & weight & 5.87 & 0.99 & 91 \\
\hline waive & 3.27 & 1.58 & 1 & wave & 5.60 & 0.91 & 46 \\
\hline want & 6.67 & 0.49 & 329 & wont & 3.67 & 2.47 & 2 \\
\hline war & 5.60 & 1.12 & 464 & wore & 5.00 & 1.96 & 65 \\
\hline ward§ & 2.80 & 0.94 & 25 & warred & 2.73 & 1.44 & 1 \\
\hline ware & 2.60 & 1.55 & 1 & wear & 6.07 & 1.39 & 36 \\
\hline weirt‡ & 1.33 & 0.61 & 2 & where§ & 6.67 & 0.49 & 938 \\
\hline warn & 5.87 & 0.99 & 11 & worn & 5.93 & 1.03 & 23 \\
\hline way§ & 6.13 & 0.99 & 909 & weigh & 5.47 & 1.25 & 4 \\
\hline we & 7.00 & 0.00 & 2653 & wee & 1.87 & 1.36 & 5 \\
\hline weak & 6.00 & 1.00 & 32 & week & 6.60 & 0.63 & 275 \\
\hline weather & 6.60 & 0.63 & 69 & whether & 6.07 & 0.80 & 286 \\
\hline weave & 4.33 & 1.84 & 4 & we've & 6.67 & 0.62 & 34 \\
\hline we'd & 6.40 & 1.35 & 32 & weed & 5.00 & 1.56 & 1 \\
\hline weir $† \ddagger$ & 1.33 & 0.61 & 2 & we're & 6.80 & 0.77 & 61 \\
\hline weld & 3.27 & 1.44 & 4 & welled & 2.13 & 0.92 & 1 \\
\hline we'll†t & 6.80 & 0.41 & 64 & wheel & 6.13 & 0.99 & 56 \\
\hline we'll†‡ & 6.80 & 0.41 & 64 & will & 6.93 & 0.26 & 2244 \\
\hline were & 7.00 & 0.00 & 3284 & whir & 2.27 & 1.16 & 3 \\
\hline which\$ & 6.73 & 0.59 & 3562 & witch & 4.27 & 2.09 & 5 \\
\hline Whig & 3.47 & 1.73 & 6 & wig & 3.93 & 1.49 & 1 \\
\hline whine & 4.40 & 1.12 & 4 & wine & 5.53 & 1.30 & 72 \\
\hline whined & 4.33 & 1.72 & 1 & wind* & 6.13 & 0.92 & 63 \\
\hline whirled & 3.53 & 1.06 & 6 & world $\S$ & 6.73 & 0.46 & 787 \\
\hline whit & 1.87 & 0.74 & 10 & wit & 5.00 & 1.07 & 20 \\
\hline
\end{tabular}


APPENDIX A (Continued)

\begin{tabular}{|c|c|c|c|c|c|c|c|}
\hline Word & $\begin{array}{c}\text { Mean } \\
\text { Familiarity }\end{array}$ & $S D$ & $\begin{array}{c}\mathrm{K} \& \mathrm{~F} \\
\text { Frequency }\end{array}$ & Word & $\begin{array}{c}\text { Mean } \\
\text { Familiarity }\end{array}$ & $S D$ & $\begin{array}{c}\mathrm{K} \& \mathrm{~F} \\
\text { Frequency }\end{array}$ \\
\hline whoa & 2.33 & 1.80 & 1 & woe & 3.00 & 1.51 & 5 \\
\hline who's & 6.80 & 0.41 & 18 & whose & 6.33 & 1.18 & 252 \\
\hline wood & 5.33 & 1.23 & 55 & would§ & 6.80 & 0.56 & 2714 \\
\hline yoke & 2.93 & 1.91 & 3 & yolk & 4.07 & 1.67 & 1 \\
\hline yore & 1.67 & 0.90 & 2 & your & 6.93 & 0.26 & 923 \\
\hline
\end{tabular}

Note-K \& F $=$ Kucera and Francis (1967). *Heteronyms. †Words with alternate pronunciations. $\ddagger$ Words rated by 30 subjects. §Words used in Experiment 2.

APPENDIX B

Filler Words from Experiments 1 and 2

\begin{tabular}{lccc}
\hline Word & $\begin{array}{c}\text { Mean } \\
\text { Familiarity }\end{array}$ & $S D$ & $\begin{array}{c}\text { K \& F } \\
\text { Frequency }\end{array}$ \\
\hline actual & 5.55 & 1.13 & 100 \\
button & 5.25 & 1.47 & 10 \\
clay & 4.25 & 1.57 & 100 \\
curls & 5.23 & 1.50 & 1 \\
echo & 4.38 & 1.40 & 10 \\
energy & 5.90 & 1.08 & 100 \\
filament & 2.55 & 1.32 & 1 \\
impute & 2.32 & 1.14 & 1 \\
margin & 5.03 & 1.34 & 10 \\
meant & 5.83 & 1.08 & 100 \\
menial & 3.83 & 1.38 & 1 \\
oily & 5.36 & 1.19 & 10 \\
places & 6.07 & 0.92 & 100 \\
scar & 4.65 & 1.42 & 10 \\
spicy & 5.13 & 1.17 & 1 \\
\hline
\end{tabular}

Note-K \& F = Kučera and Francis (1967).

(Manuscript received April 2, 1986;

revision accepted for publication August 22, 1986.) 